This article was downloaded by: [B-on Consortium - 2007]

On: 10 September 2010

Access details: Access Details: [subscription number 919435512]

Publisher Taylor \& Francis

Informa Ltd Registered in England and Wales Registered Number: 1072954 Registered office: Mortimer House, 3741 Mortimer Street, London W1T 3JH, UK

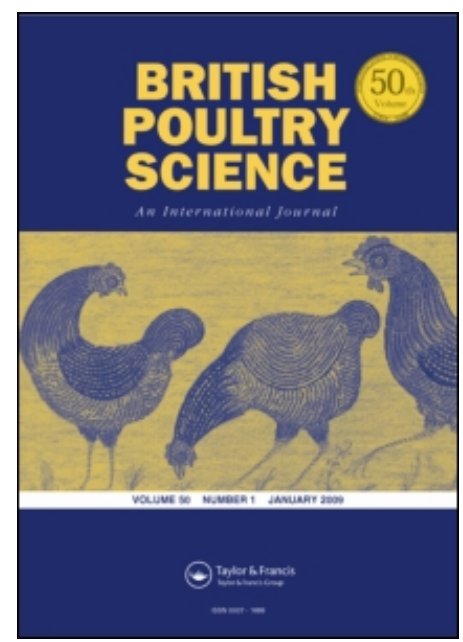

\title{
British Poultry Science
}

Publication details, including instructions for authors and subscription information:

http://www.informaworld.com/smpp/title content=t713408216

\section{In vivo toxicity study of phage lysate in chickens}

A. Oliveira ${ }^{\text {ab }}$ R. Sereno; $;$ A. Nicolau $;$ J. Azeredo ${ }^{b}$

${ }^{a}$ Research and Development Department, Controlvet, Segurança Alimentar, Tondela, Portugal b IBB, Institute for Biotechnology and Bioengineering, Centre of Biological Engineering, Universidade do

Minho, Braga, Portugal

Online publication date: 10 November 2009

To cite this Article Oliveira, A. , Sereno, R. , Nicolau, A. and Azeredo, J.(2009) 'In vivo toxicity study of phage lysate in chickens', British Poultry Science, 50: 5, 558 - 563

To link to this Article: DOI: 10.1080/00071660903141013

URL: http://dx.doi.org/10.1080/00071660903141013

\section{PLEASE SCROLL DOWN FOR ARTICLE}

Full terms and conditions of use: http://www.informaworld.com/terms-and-conditions-of-access.pdf

This article may be used for research, teaching and private study purposes. Any substantial or systematic reproduction, re-distribution, re-selling, loan or sub-licensing, systematic supply or distribution in any form to anyone is expressly forbidden.

The publisher does not give any warranty express or implied or make any representation that the contents will be complete or accurate or up to date. The accuracy of any instructions, formulae and drug doses should be independently verified with primary sources. The publisher shall not be liable for any loss, actions, claims, proceedings, demand or costs or damages whatsoever or howsoever caused arising directly or indirectly in connection with or arising out of the use of this material. 


\title{
In vivo toxicity study of phage lysate in chickens
}

\author{
A. OLIVEIRA ${ }^{1}$, R. SERENO, A. NICOLAU ${ }^{1}$ AND J. AZEREDO ${ }^{1}$ \\ Research and Development Department, Controlvet, Segurança Alimentar, S.A., Tondela, Portugal and \\ ${ }^{1} I B B$, Institute for Biotechnology and Bioengineering, Centre of Biological Engineering, Universidade do Minho, \\ Braga, Portugal
}

\begin{abstract}
Bacteriophage (phage) crude lysate of Gram-negative bacteria often contains bacterial debris, including lipopolysaccharides found in the outer membrane of the cell wall, which are potentially toxic.

2. In this study, an in vivo evaluation of the toxicity of a suspension of three phages to control pathogenic Escherichia coli strains in poultry was performed.

3. Eighteen commercial layers, 7 weeks old, were intramuscularly injected with phage lysate $\left(8.21 \times 10^{4}\right.$ Endotoxin Units/dose). The control group was injected with sterile Luria Bertani (LB) broth.

4. Bird prostration and decrease in body weight gain and water intake per gram of body weight were observed only on the day of the inoculation in the challenged group. Over the following $6 \mathrm{~d}$, no differences were observed in the chickens' activity.

5. These results support the view that phage crude lysate carrying endotoxins are not toxic for chickens.
\end{abstract}

\section{INTRODUCTION}

Lytic bacteriophages (phages) are viruses that infect and promote bacterial lysis through a multiple-step process: they multiply in the host bacteria and lyse it at the end of the cycle, after immediate replication of new phage particles. They are regarded as good candidates for antimicrobial therapy, as they provide an opportunity to control bacterial infections. Bacteriophages are safe once they exclusively infect bacterial cells, having no activity against animal or plant cells. Like all viruses, phages are metabolically inert in extracellular form and they are ubiquitous in nature (Huff et al., 2005). Nevertheless, as phage infections culminate in lysis of bacteria, there is a consequent release of cell wall components to the environment as cell debris. In this process, Gram-negative bacteria release endotoxin, whose biological activity is associated with complexes of lipopolysaccharides
(LPS), present in the outer layer membrane. This can lead to undesired side effects with phage therapy. The LPS toxicity is associated with the lipidic component of the molecule, known as "Lipid A", while the immunogenicity is associated with the polysaccharide component, known as "O-specific side chain" or "O-antigen" (Culbertson and Osburn, 1980; Prins et al., 1994; Williams, 2001b; Todar, 2002; Boratyński et al., 2004). Thus, LPS are present in the cellular debris in crude phage lysates, easily passing through filters used to remove whole bacteria from phage suspensions (Williams, 2001b).

The endotoxins induce a variety of inflammatory responses, being often part of the pathology of Gram-negative bacterial infections. Although animals vary in their susceptibility to endotoxins, the sequence of pathophysiological reactions follows a general pattern: a latent period followed by physiological distress. Immunologic and neurological system activation,

Correspondence: Dr J. Azeredo, IBB, Institute for Biotechnology and Bioengineering, Centre of Biological Engineering, Universidade do Minho, Campus de Gualtar, 4710-057 Braga, Portugal. E-mail: jazeredo@deb.uminho.pt

Accepted for publication 4th February 2009. 
induction of blood coagulation, general metabolic effects, alteration of blood cell populations, pyrogenicity, production of endotoxic shock and hepatotoxicity are some of the known reactions to an endotoxin parenteral challenge, promoting symptoms like fever, diarrhoea, prostration and, in many cases, shock and death (Culbertson and Osburn, 1980; Williams, 2001a). Removal of endotoxins from solutions intended to be used in humans or animals is therefore an important area for study, but the success of this procedure is dependent on the initial composition of the mixture (Petsch and Anspach, 2000; Boratyński et al., 2004). Ultrafiltration and size-exclusion chromatography should theoretically provide a way of separating components differing in molecular mass. However, the application of these two down stream processes in the purification of phages removes only some of the contaminants present in the phage suspension. Despite their relatively low molecular weight (4-20 kDa for LPS monomer), endotoxins are not effectively removed as they tend to aggregate forming structures similar to micelles and vesicles, ranging in molecular weight from 300000 to 1 million, with diameters up to $0 \cdot 1 \mu \mathrm{m}$ (Williams, 2001b; Boratyński et al., 2004). Other approaches to achieving destruction or removal of endotoxins, like hydrolysis with acid or base, oxidation, alkylation, heat treatment and treatment with polymicin B have been reported (Davies, 1999). However, the economical viability of scaling up the process and the possibility of compromising the recovery rate of the phages needs evaluation. Petsch and Anspach (2000) report that the question of economical endotoxin removal has occupied many investigators and has been the reason for process rearrangements.

Our in vivo trial with an $E$. coli phage crude lysate, administered intramuscularly to chickens, was conducted in order to evaluate the endotoxin effect and to assess the importance of endotoxin removal in ensuring the safety of this phage product for the target species.

\section{MATERIALS AND METHODS}

\section{E. coli phage lysate}

Crude phage suspensions were prepared by inoculating a single phage plaque of the phages phi $\mathrm{F} 78 \mathrm{E}$, phi F258E and phi $\mathrm{F} 61 \mathrm{E}$ in $10 \mathrm{ml}$ of the respective E. coli host $\mathrm{H} 561 \mathrm{E}, \mathrm{H} 816 \mathrm{E}$ and H161E, mid-log grown (3-4 h) into Luria Bertani (LB) broth (Sigma) (Oliveira et al., 2009). This was followed by overnight incubation at $37^{\circ} \mathrm{C}$ with shaking $(120 \mathrm{rpm})$. The suspension was centrifuged $(9000 \times g$ ) for $10 \mathrm{~min}$ (rotor 19776 , Sigma 3-16k), filtered through a $0 \cdot 22-\mu \mathrm{m}$ membrane (Millipore) and, following the same procedure as previously, inoculated again in $100 \mathrm{ml}$ of mid-log grown culture of the respective E. coli host. Incubation was performed at $37^{\circ} \mathrm{C}$ with shaking $(120 \mathrm{rpm})$, centrifugation was at $9000 \times g$ for $10 \mathrm{~min}$ and filtration was through $0.22 \mu \mathrm{m}$. The phage crude lysate was stored at $4^{\circ} \mathrm{C}$. The number of phages in this suspension was determined as described by Adams (1959) with minor modifications. Successive dilutions of the phage suspension were performed in phage buffer $(100 \mathrm{mmol} / \mathrm{l} \mathrm{NaCl}$ (Sigma), $8 \mathrm{mmol} / \mathrm{l}$ $\mathrm{MgSO}_{4}$ (Sigma), $50 \mathrm{mmol} / \mathrm{l}$ Tris (Sigma), $\mathrm{pH} 7.5)$ and $100 \mu \mathrm{l}$ of each dilution together with $100 \mu \mathrm{l}$ of the respective bacteria host suspension were mixed with $3 \mathrm{ml}$ of LB $0.6 \%$ top agar layer and placed over a $1.5 \%$ LB agar bottom layer. Plates were incubated at $37^{\circ} \mathrm{C}$ for $12 \mathrm{~h}$ and phages enumerated in the higher dilution with distinct plaques. Phage titration was performed in triplicate.

\section{Measurement of endotoxin concentration}

The concentration of LPS present in the E. coli phage lysate was measured using the Limulus Amebocyte Lysate assay (LAL) (Bio-Whittaker), which is based on the activation of Limulus Lysate by endotoxins (Prins et al., 1994). The procedure was as instructed by the supplier, using a spectrophotometer (Bio-TEK Synergy HT). This method was approved by FDA for detection and quantification of endotoxins (FDA, 1985).

\section{Experimental design}

This study was conducted according to the Federation of European Laboratory Animal Science Associations (FELASA) principles of animal welfare, and the experiment was designed in accordance to the European Council Directive of 24 November 1986 (86/609/EEC) guidelines, on the approximation of laws, regulations and administrative provisions of the member States regarding the protection of animals used for experimental and other scientific purposes.

Thirty-six healthy 7-week-old growers (Rhode Island Red) were used. Two groups of 18 chickens were selected at random and housed, three per cage, in a temperature and relative humidity controlled animal room, with a $12 \mathrm{hL}: 12 \mathrm{hD}$ cycle. Birds were individually identified by leg rings. Feed and water were provided ad libitum. A volume of $1 \mathrm{ml}$ of the previously prepared phage suspension and $1 \mathrm{ml}$ of sterile LB broth were injected intramuscularly, respectively in the challenged group (CHG) and in the control group (CG), only on the first day. The chickens' body weight (BW) was recorded the day before and every day after challenge. 


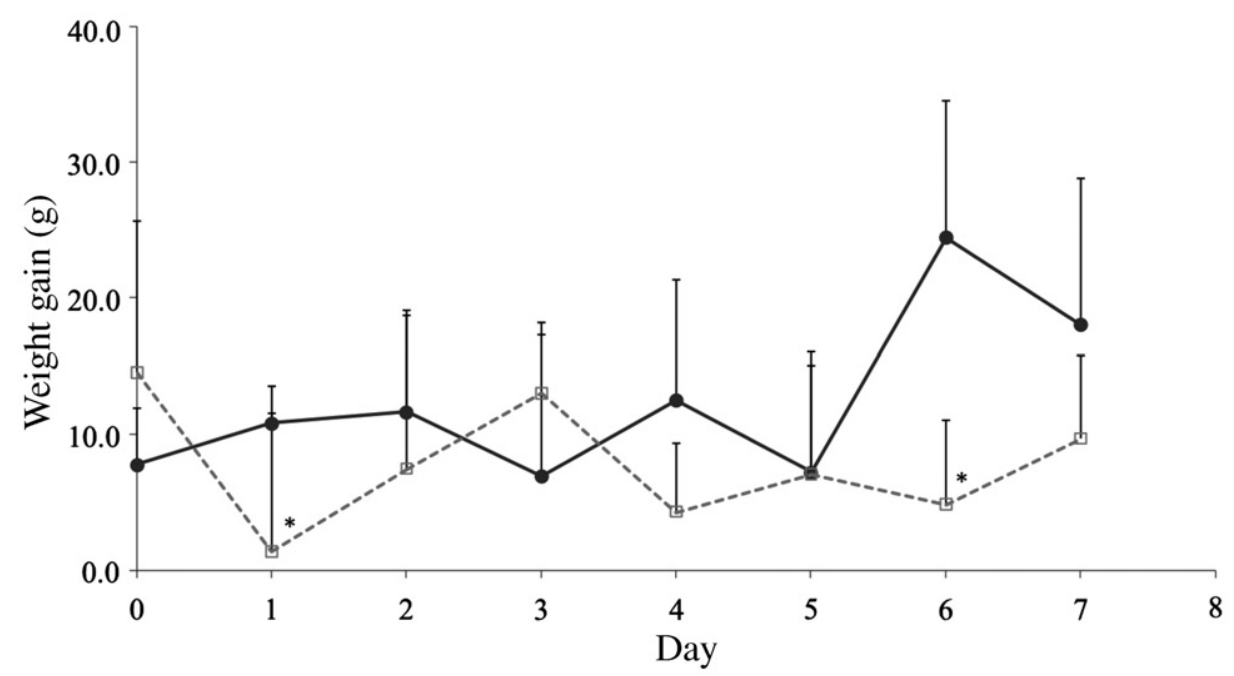

Figure 1. Chickens' daily BW gain. In the figures, the solid line represents $C G$ variation in body weight gain and the dashed line represents the CHG variation. Error bars represent standard deviations of experimental data from the 6 cages of three animals each. *Statistically different from CG.

In order to avoid unnecessary discomfort to the animals, the evaluation of chickens' reaction to challenge was based on behavioural observations. Healthy chickens were recognised by their standing position, with neck strong and straight, flat feathers against the body and high frequency of seeking food and water. In contrast, if chickens were sitting, lying still, with the neck weak and drawn in, raised feathers, and not seeking food or water, they were reported as prostrate. Food and water consumption were recorded daily. On day 7, all chickens were humanely killed by isofluorane (IsoFlo ${ }^{\circledR}$, Abbott) inhalation and submitted to post mortem examination.

\section{Statistical analysis}

Statistical analysis was undertaken for all dependent variables: BW gain, feed and water intake per gram of BW. CHG means were compared with CG means at each data collecting period. Statistical variance analysis was performed using Kruskal-Wallis test in SPSS v15.00 software. Statistical significance was defined as $P=0.05$.

\section{RESULTS}

\section{E. coli phage lysate}

The E. coli phage lysate is a mixture of three phages phi F78E, phi F258E and phi $\mathrm{F} 61 \mathrm{E}$, with the concentration of each phage being $1.67 \times 10^{8} \mathrm{pfu} / \mathrm{ml}, 2.5 \times 10^{8} \mathrm{pfu} / \mathrm{ml}$ and $3.0 \times 10^{8} \mathrm{pfu} / \mathrm{ml}$, respectively. The LAL test revealed that the LPS concentration present in this suspension was $8.21 \times 10^{4}$ Endotoxin Units $(\mathrm{EU}) / \mathrm{ml}$

\section{In vivo challenge with phage lysate}

A volume of $1 \mathrm{ml}$ of phage lysate was administered intramuscularly to the chickens of the CHG, with the total amount of LPS being, on average, $2.32 \times 10^{5} \mathrm{EU} / \mathrm{kg} \mathrm{BW}$.

During the in vivo experiment, bird prostration was observed only on the day of the inoculation (day 1) in CHG. One bird died one hour after inoculation but post mortem analysis detected no macroscopic lesions in the internal organs. During the following $6 \mathrm{~d}$ there were no visual differences in activity between the two groups. Regarding BW gain (Figure 1), on day 1 and day 6 , this variable decreased in CHG birds $(P=0.043$ and $P=0.010$, respectively). Feed and water intake per gram of $\mathrm{BW}$ did not diverge significantly between groups (Figures 2 and 3). Water intake per gram of BW at day 1 decreased in CHG birds, but with no relevant differences between groups $(P=0 \cdot 065)$. On day 4 , there was a decrease $(P=0.035)$ in CHG, however this tendency was no longer observed in the following days.

\section{DISCUSSION}

Phage therapy has been considered an important alternative to the administration of antibiotics in the treatment of severe $E$. coli infections in birds (Huff et al., 2004, 2005). One concern is the presence of endotoxins in the phage crude lysate (Projan, 2004). In the present work, $8.21 \times 10^{4} \mathrm{EU} / \mathrm{ml}$ LPS were found in the prepared phage cocktail used. Nevertheless, the chickens were challenged with $1 \mathrm{ml}$ of this phage lysate containing approximately $2.32 \times$ $10^{5} \mathrm{EU} / \mathrm{kg} \mathrm{BW}$, which was not supposed to be lethal, since, and according to Culbertson and 


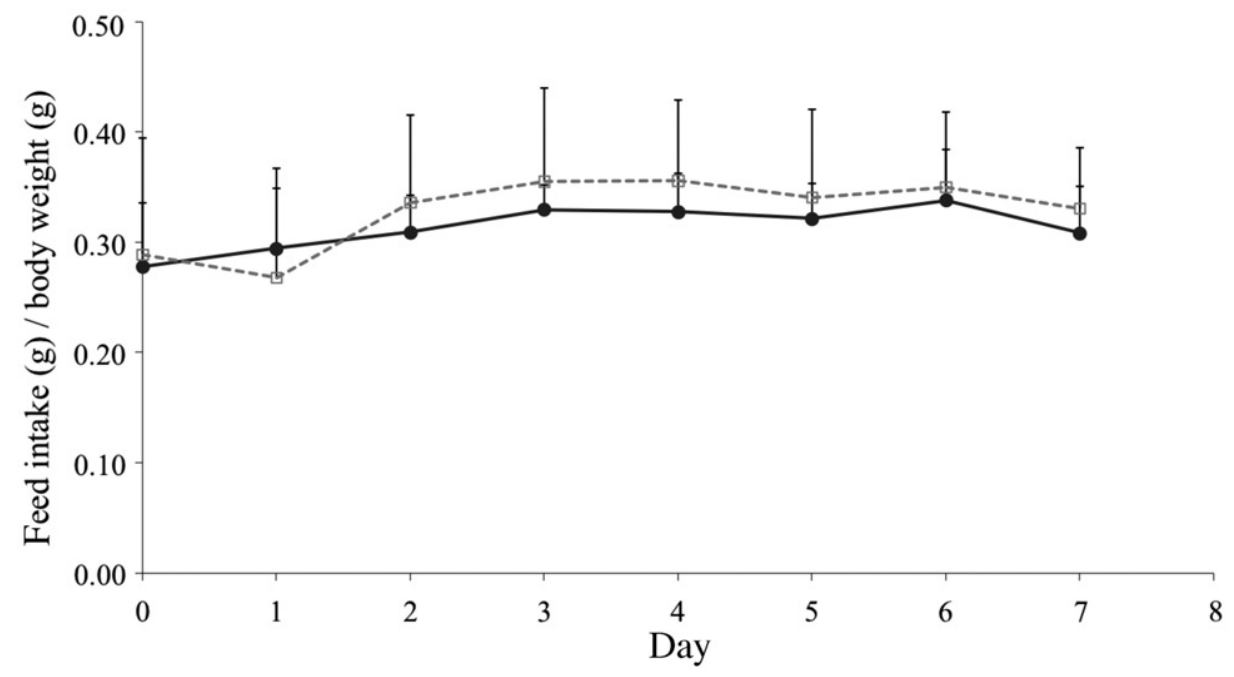

Figure 2. Chickens' feed consumption per gram of BW. In the figures, the solid line represents CG variation in body weight gain and the dashed line represents the CHG variation. Error bars represent standard deviations of experimental data from the 6 cages of three animals each.

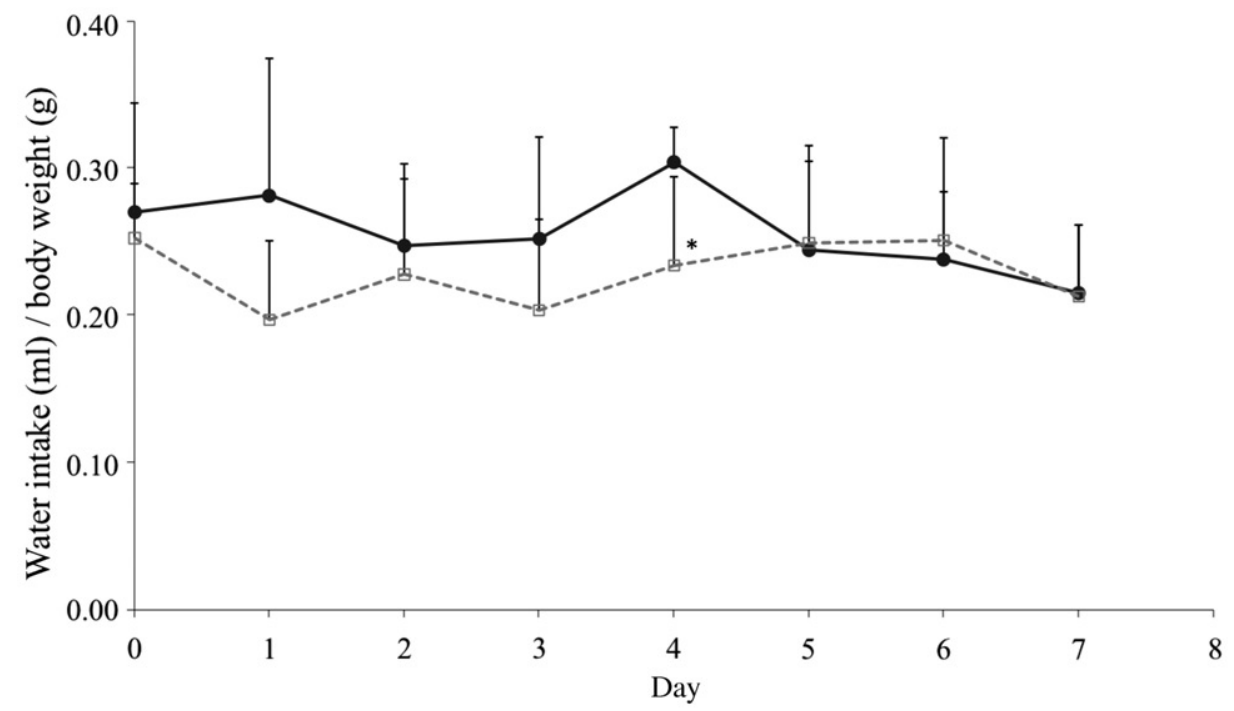

Figure 3. Chickens' water consumption per gram of BW. In the figures, the solid line represents CG variation in body weight gain and the dashed line represents $C H G$ variation. Error bars represent standard deviations of experimental data from the 6 cages of three animals each. *Statistically different from $C G$.

Osburn (1980), the lethal dose of Escherichia coli endotoxins to chickens is $\geq 50 \mathrm{mg} / \mathrm{kg}$ or $\geq 5 \times$ $10^{8} \mathrm{EU} / \mathrm{kg} \quad(1 \mathrm{EU} / \mathrm{ml} \approx 10 \mathrm{ng} / \mathrm{ml})$. Kokosharov (2002) reported that little is known about LPS activity in chickens and sometimes experimental data are conflicting and divergent. The phage lysate we administered has 10 times the volume, and therefore might have about 10 times the LPS content of the phage cocktails used for therapeutic purposes by Huff et al. $(2004,2005)$. These authors did not observe any harmful effects on chickens' health and advise phage concentration in therapeutic mixtures ranging between $10^{7}$ and $10^{9} \mathrm{pfu} / \mathrm{ml}$ (Huff et al., 2004, 2005).

During the in vivo trial, the birds challenged with the phage lysate, as compared to the CG, exhibited prostration and decreased feed and water intake only during the day of inoculation: subsequently, chickens' behaviour did not show visual differences between groups. Similar findings were reported by Smith et al. (1978) during an experiment with endotoxins from Salmonella enterica serovar Gallinarum administered to 14-dold chicks. Despite the observation of some clinical illness without mortality a few hours after intravenous injection of $1.5 \times 10^{7} \mathrm{ng} / \mathrm{kg}$ LPS, most of the responses returned to normal within 24-48 h. Also Kokosharov (2002) observed illness in cockerels one hour after injection of $5.0 \times 10^{7} \mathrm{ng} / \mathrm{kg}$ LPS. Birds were described as standing in the corners of the cages with signs of depression, reluctance to move, somnolence, 
loss of thirst and appetite, and diarrhea, which all gradually disappeared. This author did not report any death among the cockerels challenged.

In the present work, one chicken died one hour after the intramuscular inoculation, probably due to anaphylactic shock, as no visible lesions were found at necropsy. The statistically significant decrease of BW gain in CHG at day 1 was probably due to the chickens' prostration and apparent loss of appetite. On day 6, the differences between groups may be explained by the occurrence of an unexpected factor during the experiment: some feeders of the CG were found empty in the morning, for the first time since the beginning of the housing. As feed had to be provided ad libitum, feeders were immediately refilled. This happened a few hours before birds weighing and thus might had contributed to the higher average weight in the CG. Regarding water intake, the non-significant decrease on day 1 in CHG was probably due to the birds' prostration. There is no explanation for the significant decrease in water intake on day 4 . However, because water intake was thereafter similar in the two treatments, this difference was probably not meaningful.

The absence of macroscopic lesions in the internal organs of the euthanised birds suggested that the phage lysate did not cause any visible internal injurious effect.

For pharmaceutical purposes there are many studies evaluating endotoxic effects in humans and other animals, like toxicity evaluation of antibiotic-induced endotoxin release, water purification for dialysis, and so on (Mathison \& Ulevitch, 1979; Shenep et al., 1985; Røkke et al., 1988; Natanson et al., 1990; Friedland et al., 1993; Martich et al., 1993; Nakamura et al., 1998; Brüssow, 2005). However, the variation in sensitivity to endotoxin among species and the higher resistance of chickens to endotoxin effects as compared to mammals (Butler et al., 1977; Smith et al., 1978; Culbertson \& Osburn, 1980; Jones et al., 1981), means that results from trials with other animals are of limited relevance to our findings.

In conclusion, apart from the immediate short term reduction in activity, no adverse effects were found in chickens challenged by phage crude lysate containing $8.21 \times 10^{4} \mathrm{EU} / \mathrm{ml}$ endotoxins, suggesting that phage crude lysate is not toxic for chickens.

\section{ACKNOWLEDGEMENTS}

The authors gratefully acknowledge the Portuguese Foundation for Science and Technology, for the financial support of this work through the grant SFRH/BDE/15508/2004.

\section{REFERENCES}

Adams, M.H. (1959) Bacteriophages (New York, Interscience). Boratyński, J., Syper, D., Weber-Dabrowska, B., ŁusiakSzelachowska, M., Poźniak, G. \& Górski, A. (2004) Preparation of endotoxin-free bacteriophages. Cellular and Molecular Biology Letters, 9: 253-259.

BRÜssow, H. (2005) Phage therapy: the Escherichia coli experience. Microbiology, 151: 2133-2140.

Butler, E.J., Curtis, M.J. \& Harry, E.G. (1977) Escherichia coli endotoxin as a stressor in the domestic fowl. Research in Veterinary Science, 23: 20-23.

Culbertson JnR, R. \& Osburn, B.I. (1980) The biologic effects of bacterial endotoxin: a short review. Veterinary Science Communications, 4: 3-14.

Davies, J.R. (1999) Process for removing endotoxins, US Patent (5917022).

FDA (1985) Bacterial endotoxins/pyrogens, Inspector's Technical Guide (USA, Department of Health and Human Services).

Friedland, I.R., Jafari, H., Ehrett, S., Rinderknecht, S., Paris, M., Coulthard, M., Saxen, H., Olsen, K. \& McCracken, G.H. (1993) Comparison of endotoxin release by different antimicrobial agents and the effect on inflammation in experimental Escherichia coli meningitis. The Journal of Infectious Diseases, 168: 657-662.

Huff, W.E., Huff, G.R., Rath, N.C., Balog, J.M. \& Donogue, A.M. (2004) Therapeutic efficacy of bacteriophage and Baytril (Enrofloxacin) individually and in combination to treat colibacillosis in broilers. Poultry Science, 83: 1944-1947.

Huff, W.E., Huff, G.R., Rath, N.C., Balog, J.M. \& Donoghue, A.M. (2005) Alternatives to antibiotics: utilization of bacteriophage to treat colibacillosis and prevent foodborne pathogens. Poultry Science, 84: 655-659.

Jones, C.A., Edens, F.W. \& Denbow, D.M. (1981) Rectal temperature and blood chemical responses of young chickens given E. coli endotoxin. Poultry Science, 60: 2189-2194.

Kokosharov, T. (2002) Clinical and hematological effects of Salmonella gallinarum endotoxin in cockerels. Veterinarski Arhiv, 72: 269-276.

Martich, G.D., Boujoukos, A.J. \& Suffredini, A.F. (1993) Response of man to endotoxin. Immunobiology, 187: 403-416.

Mathison, J.C. \& Ulevitch, R.J. (1979) The clearance, tissue distribution, and cellular localization of intravenously injected lipopolysaccharide in rabbits. The Journal of Immunology, 123: 2133-2143.

Nakamura, K., Mitarai, Y., Yoshioka, M., Koizumi, N., Shibahara, T. \& Nakajima, Y. (1998) Serum levels of interleukin-6, alpha1-acid glycoprotein, and corticosterone in two-week-old chickens inoculated with Escherichia coli lipopolysaccharide. Poultry Science, 77: 908-911.

Natanson, C., Danner, R.L., Reilly, J.M., Doerfler, M.L., Hoffman, W.D., Akin, G.L., Hosseini, J.M., Banks, S.M., Elin, R.J., Macvittie, T.J. \& Parrillo, J.E. (1990) Antibiotics versus cardiovascular support in a canine model of human septic shock. American Journal of Physiology, 259: 1440-1447.

Oliveira, A., Sillankorva, S., Henriques, A., Quinta, R., SERENo, R. \& Azeredo, J. (2009). Isolation and characterization of bacteriophages for avian pathogenic E. coli strains. Journal of Applied Microbiology, 106: 1919-1927.

Petsch, D. \& Anspach, F.B. (2000) Endotoxin removal from protein solutions. Journal of Biotechnology, 76: 97-119.

Prins, J.M., Van Deventer, S.J., Kuijper, E.J. \& Speelman, P. (1994) Clinical relevance of antibiotic-induced endotoxin release. Antimicrobial Agents and Chemotherapy, 38: 1211-1218. 
Projan, S. (2004) Phage-inspired antibiotics? Nature Biotechnology, 22: 167-168.

RøkKe, O., Revhaug, A., Østerud, B. \& Giercksky, K.E. (1988) Increased plasma levels of endotoxin and corresponding changes in circulatory performance in a porcine sepsis model: the effect of antibiotic administration. Progress in Clinical Biological Research, 272: 247-262.

Shenep, J.L., Barton, R.P. \& Mogan, K.A. (1985) Role of antibiotic class in the rate of liberation of endotoxin during therapy for experimental gram-negative bacterial sepsis. The Journal of Infectious Diseases, 151: $1012-1018$.

Smith, I.M., Licence, S.T. \& Hill, R. (1978) Haematological, serological and pathological effects in chicks of one or more intravenous injections of Salmonella gallinarum endotoxin. Research in Veterinary Science, 24: 154-160.

TOdar, K. (2002) Mechanisms of bacterial pathogenicity: endotoxins. Online Textbook of Bacteriology. Department of Bacteriology, University of Wisconsin-Madison. URL: http://www.textbookofbacteriology.net/endotoxin.html

Williams, K.L. (Ed.) (2001a) Pyrogen, endotoxin and fever: an overview, in: Williams, K.L. (Ed.) Endotoxins, Pyrogens, LAL Testing, and Depyrogenation, Vol. III, Ch. 2, 2nd edn, pp. 12-26 (New York, Marcel Dekker, Inc.).

Williams, K.L. (Ed.) (2001b) Endotoxin structure, function and activity, in: Williams, K.L. (Ed.) Endotoxins, Pyrogens, LAL Testing, and Depyrogenation, Vol. III, Ch.3, 2nd edn, pp. 27-38 (New York, Marcel Dekker, Inc.). 